\title{
Atentados ao Choque Tecnológico?
}

\author{
De "Reforma" em "Reforma"... até... à Aposentação final.*
}

Não há choque tecnológico que resista sem que haja ensino e quadros científicos com uma forte componente de Matemática, Física e Química. Não por estas disciplinas serem mais importantes, mas porque constituem os fundamentos da Geologia, Biologia, Biotecnologia, etc., e das diversas Engenharias. Reduzindo ao absurdo, não se pode fazer cálculos numéricos complexos sem conhecer os algarismos, assim como não se pode desenhar pontes sem saber efectuar balanços de forças.

A Sociedade Portuguesa de Química está muito apreensiva com as deliberações da "Comissão Nacional de Acesso ao Ensino Superior", que estão baseadas numa série de decretos-leis anteriormente publicados. As deliberações desta comissão conjugadas com a escoIha das provas de ingresso por parte das Universidades estão a levar o ensino secundário a um beco sem saída, e em particular ao esvaziamento da Química. Como se não bastasse o Conselho de Reitores (CRUP) fez circular uma proposta normativa onde a disciplina de Biologia e Geologia (bianual) deveria ser, em detrimento da Química e da Biologia, a disciplina de acesso às licenciaturas em Bioquímica, Biotecnologia, Medicina, Ciências Farmacêuticas, e Análises Clínicas. No caso do acesso às licenciaturas em Engenharia Química era apontada apenas a necessidade da disciplina de Matemática. Não há informação que esta proposta tenha, entretanto, caído.

1 Secretário Geral da Sociedade Portuguesa de Química (fjp@dq.fct.unl.pt)
Em consonância, as próprias Universidades estão a alargar em muitas licenciaturas o leque de provas de ingresso em alternativa, a fim de não perderem alunos. Neste momento, é possível um aluno concluir o ensino secundário, na área de Ciências e Tecnologias, sem ter alguma vez frequentado do $10 .^{\circ}$ ao $12 .^{\circ}$ ano uma disciplina de Química. Por exemplo: no $10 .^{\circ}$ ano escolhe apenas Biologia e Geologia como disciplina opcional da formação específica; no $11 .^{\circ}$ Ano escolhe Desenho e Geometria Descritiva A, Aplicações Informáticas B ou Economia A como 2. ${ }^{\text {a }}$ disciplina opcional da formação específica. Neste quadro nunca poderá escolher nem Física nem Química como disciplina opcional no $12 .^{\circ}$ Ano. E conclui os seus estudos secundários. $\mathrm{E}$ poderá ter lugar em algumas licenciaturas da área da Química e da Física (www.acessoensinosuperior.pt).

Facto: no próximo ano lectivo as turmas de Química do $12 .^{\circ}$ ano serão quase completamente varridas das escolas e substituídas por Geologia, Biologia, Psicologia ou mesmo Ciência Política. Claro que Geologia é uma Ciência fascinante tal como a Biologia que certamente será útil aos futuros médicos e a todos os alunos que pretendam frequentar ciências e tecnologias. Mas não seria mais formativo começar a construir a casa pelos caboucos?

As Ciências Químicas e afins são das áreas mais produtivas da investigação científica e tecnológica em Portugal, e uma passagem pela Web of Science pode ser muito esclarecedora. Permitam-me que cite um estudo do Prof. Sebastião Formosinho (www.qui.uc.pt)
“Das 8 Universidades portuguesas (UTLIST, Coimbra, Porto, Aveiro, UNL, Minho, Algarve e U. Lisboa) que possuem pelo menos uma área científica colocada num ranking mundial, a Química aparece em 5 destas universidades como a área científica de domínio forte e em três delas aparece em 1. ${ }^{\circ}$ Iugar. Mais nenhuma área científica em Portugal atinge tal performance. Portanto, algumas das nossas universidades dispõem de motores de competitividade, mas em número relativamente limitado. A Química é pois a área científica mais forte do nosso país, com cinco universidades (Coimbra, IST, UNL, Aveiro e Porto) em que a Química está no top 1\% mundial".

Estamos a comprometer uma área científica em que somos realmente bons, e com enorme internacionalização.

Quando se perceber que as disciplinas ditas difíceis porque mais estruturantes e exigentes, Matemática, Física e Química, são a pedra de toque de uma reforma que conduza à excelência, à inovação e ao tal choque tecnológico; quando se perceber que não é fazendo os estudantes escolher as disciplinas mais fáceis que se ganha o futuro, nesse dia pode haver esperança.

*Publicado no jornal Público a 29-07-2006 


\section{Mineralogia Industrial Princípios e Aplicações}

Lidel - edições técnicas, Ida

Os minerais fazem parte do nosso dia-a-dia, sendo que muitas vezes, algumas sem nos apercebermos, nos cruzamos com materiais que resultam da transformação dos mais diversos minerais. Nunca o Homem recorreu com tanta intensidade aos minerais como na actualidade. As grandes potências económicas baseiam muito do seu potencial nestes recursos e sem eles não seria possível manter o nível de vida das sociedades desenvolvidas.

Com o objectivo de apresentar os principais minerais e suas aplicações surgiu a presente obra que, pelo modo como se encontra organizada e apresentada, é facilmente compreendida por leitores de diferente formação científica e cultural.

Este livro constitui-se por duas partes fundamentais: a primeira apresenta os minerais industriais dispostos por ordem alfabética, para tornar mais fácil ao leitor a sua consulta, e analisados dos pontos de vista da sua Mineralogia, Ocorrências, Tecnologia, Aplicações e Mercado; a segunda aborda, com pormenor, um conjunto de materiais de uso comum que se baseiam essencialmente nos minerais industriais.

Debruçando-se sobre o estudo das aplicações dos minerais para múltiplos fins, a maioria deles de uso corrente, Mineralogia Industrial - Princípios e Aplicações dirige-se fundamentalmente a estudantes e docentes das áreas da Geologia, das Engenharias Geológicas, do Ambiente, de Minas, de Georrecursos, Civil, Cerâmica e Vidro, de Materiais, Metalúrgica, Física e Química, procurando, também, ser um instrumento de consulta útil para os profissionais da indústria extractiva e transformadora e para os investigadores com interesse nos minerais industriais. Este manual pode, igualmente, ser apreciado pelo cidadão comum curioso destas matérias.

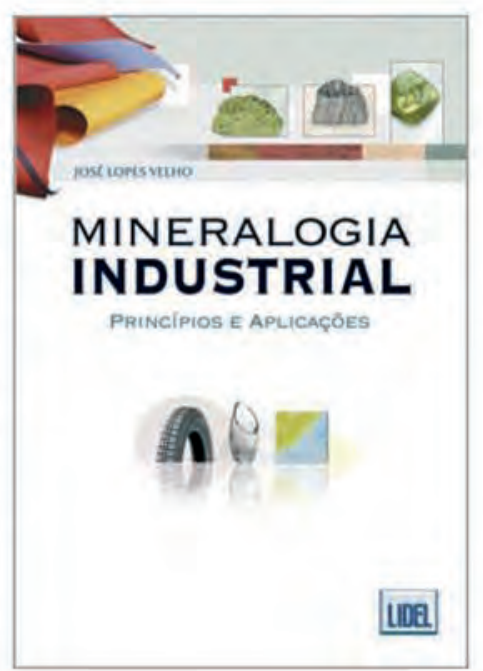

\section{Contúứdolo}

- Minerais industriais (argilas, agregados, zeólitos, gesso, talco, salgema, sílica, rochas ornamentais, alumínio, asbestos, micas, manganés, magnesite, terras raras, entre outros) - Materiais (abrasivos, papel, tintas, plásticos, cerâmicos, vidro, cimento, borracha, entre outros)

\section{Público Alvo}

- Geólogos - Engenheiros Geólogos, Cerâmicos e de Materiais, Civis, Químicos, Físicos e do Ambiente • Estudantes Universitários • Investigadores •| Industriais • Técnicos que trabalham na indústria mineral e em materiais

\section{Autor}

José Lopes Velho - Licenciado em Geologia pela Universidade de Coimbra, é Professor Associado do Departamento de Geociências da Universidade de Aveiro. Possui o Grau de Mestre em Geologia Económica e Aplicada pela Universidade de Lisboa e o Grau de Doutor em Geociências, especialidade Mineralogia, pela Universidade de Aveiro. É membro da Unidade de Investigação Minerais Industriais e Argilas.

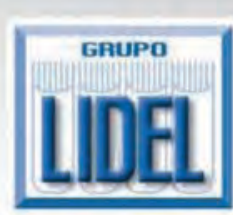

À venda nas livrarias e na:

LIDEL - Edições Técnicas, Lda.

Av. Praia da Vitória n० 14, 1000-247 Lisboa

Tel: $213541418 / 213511448 *$ Fax: 213173259

E-mail: livrarialx@lidel.pt

Porto: 225573510 * Coimbra: 239822486

E-mail: lidel@lidel.pt * URL: http://www.lidel.pt
ISBN:

N. de Páginas:

Formato:

Especialidade:

P.V.P.:

$\begin{array}{ll}\text { P.V.P.: } & \boldsymbol{€} \mathbf{4 4 , 4 0} \\ \text { P.V.P.(C/ 10\%) Ao Sócio da SPQ: } & \boldsymbol{€} 39,96\end{array}$

Válido até $\mathbf{3 0}$ de Setembro
972-757-331-2

624

$17 \times 24 \mathrm{~cm}$

Engenharia \& Geologia

39,96 